\title{
CMALT 2011 and 2021: Personal Narratives for Professional Recognition
}

\author{
Elizabeth A. Beckmann
}

Beth Beckmann \& Associates

\section{Lynn C. Gribble}

School of Management and Governance, University of New South Wales

Professional recognition through Certified Membership of the Association for Learning Technology (CMALT) provides a significant opportunity for all those who use learning technologies to be acknowledged for their experience, capabilities, and practice. The CMALT portfolio requires a personal narrative that presents description, critical reflection, and evidence of professional practice. Through an experiential lens, this paper considers three facets of the authors' CMALT experiences a decade apart - how the portfolios as personal narratives encouraged reflection on practice; the commonalities in the technology themes presented in those portfolios; and how reflective coaching contributed to the benefits of applying for CMALT.

Keywords: CMALT, professional recognition, reflective coaching, personal narrative

\section{Introduction}

Launched in 2004 as a professional recognition (PR) initiative of the UK-based Association for Learning Technology (ALT), Certified Membership of the ALT (CMALT) is awarded through peer-assessment of a portfolio that details, and reflects upon, an applicant's experience using learning technologies. This paper explores two CMALT portfolios developed 10 years apart in 2011 and 2021 - a decade that saw phenomenal innovation in technologies and the 2020-21 pandemic driving a global shift to online learning in all educational sectors. Through an experiential lens, this paper considers three facets of the authors' CMALT experience a decade apart - how the portfolios as personal narratives encouraged reflection on practice; the commonalities in the technology themes presented in those portfolios; and how reflective coaching contributed to the benefits of applying for CMALT.

\section{Personal Narratives as Tools for Professional Recognition}

According to the CMALT Guidelines, the portfolio submitted for CMALT review may contain text, visual and/or audio elements, and is expected to be "of a reflective and analytical nature and not solely descriptive ... personal ... in the first person singular" (Association for Learning Technology, 2016, 3). These features characteristically describe personal narratives - accounts of "a past experience in the order it happened from the point of view of a narrator who interprets the significance of the experience" (Langellier, 1989, 245). Often used for inquiry in the social sciences, personal narratives also have a significant place in research related to professional practice, including teaching with technologies. For example, within the context of the COVID-19 pandemic driving a global shift to online learning, Kara et al (2020) analysed the narrative stories of two academics using social media in teaching; Sellers et al (2021) reviewed narratives in relation to the affective dimensions of mentoring; and Anderson et al (2020) considered academics' narratives in their pandemicrequired journey into professional development in online learning.

Personal narratives have also gained an almost universal place in the process of standard- or criterion-based PR and esteem in higher education practice, whether this recognition is embodied in qualifications, teaching awards, or fellowships or memberships of professional bodies. Dot-point lists of output metrics have largely been replaced with personal storytelling that illustrates the applicant's practice through description, critical reflection and evidence (e.g., Beckmann, 2016; Bornais and Buchholz, 2018; Kuiper and Stein 2019). 
ASCILITE 2021

Back to the Future

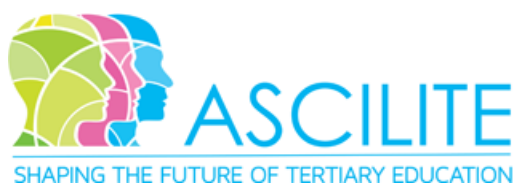

This emphasis appears more closely tied to the notion of scholarly practice rather than scholarship per se:

Scholarly teaching is reflective, based on knowledge of what works, applying the literature ... and ... risk taking in ... new or adapted pedagogical approaches, and the evaluation of their effect on student learning (Benson, Smith \& Eubanks, 2013, 224).

Langellier (1989) suggests personal narratives may be viewed from five perspectives - as story-text, storytelling performance, conversational interaction, social process, and political praxis. All five are pertinent to reflective accounts put forward for peer review of educational practice. Successful applicants generally tell conversational first-person 'stories' of performative practice that indicate social learning and social engagement with students ('student-centred', 'two-way' 'interactive', 'students as partners') and colleagues ('collaborative', 'cooperative', 'team-based'). Moen $(2006,60)$ argues that the very nature of a narrative is that its story has significance for the narrator or the audience: the peers who review these narratives are thus themselves integral to the process. They must engage with the diversity of individual contexts and narrative styles; apply criteria and standards accordingly; differentiate sufficiently between description and reflection; and give effective feedback, if necessary, to guide the applicant to a more appropriate stance. CMALT assessors seek to identify convincing evidence of reflective practice (Association for Learning Technology, 2019). The nature of such assessments necessarily require a level of subjective as well as objective analysis, so reviewers of reflective narratives tend to be selected not just from groups of peers but from those considered expert peers.

Langellier's (1989) concept of narrative as political praxis is also relevant. Many professional recognition schemes require adherence to identified values. A CMALT core principle is "an empathy with and willingness to learn from colleagues from different backgrounds and specialist areas" (Association for Learning Technology, 2016, 3), and the Assessment Guidelines 2019 state that "Learning Technology professionals have an important role to play in helping to develop informed and ethical use of technology" (Association for Learning Technology, 2019, 3). Practices across disciplines, cultures and institutions are expected to vary, but scholarly thinking and research strongly suggests some educational practices may be more acceptable to assessors than others. For example, assessors' reactions to practices that an applicant presents as 'studentcentered', 'inclusive' and/or 'interactive' are more likely to be positive than their reactions to practices that revolve around 'rote learning', 'exam-only assessment' or 'humiliation'. Imagine the shock of assessing an application that describes a commitment to 'injury-based learning' - and then the amused relief when the very doubtful practice is recognised as a simple typographical error (replacing 'qui' with 'ju'). However, understanding the natural subjectivity and appropriate value-laden aspect of peer review suggests that those writing about their own practice must consider what constitutes an appropriate reflective stance in their context, and how to present themselves in a way that is complex, but not contentious. Some researchers argue that at least one form of professional recognition — teaching excellence awards - has already developed as:

a genre with associated normative expectations ... only those who also achieve the skillful presentation of self through the mediation of the written word will be recognised as excellent (Kuiper and Stein 2019, 1210-1211).

Noting this possibility of writing 'to order' rather than being unfiltered in one's presentation of self, there is also a positive corollary that comes from learning to write within the 'genre' of professional recognition for teaching excellence. Most educators' sense of identity is strongly connected to both their practice and to their relationships with their learners and other practitioners (Gallardo, 2019). In this context - of helping potential applicants unpack, rationalise and make meaning of their practices - peers become important not only as assessors but even more importantly as supporters of the process of reflection itself. One clear aim of requiring personal narratives for recognition is the opportunity for the dialectic of thinking and writing to stimulate professional learning.

A critical factor is thus not so much the personal nature of the narrative but rather "the context of the reflection and the depth of thought and inquiry that it encourages" in which the reflections give the writer the "cognitive challenges and high levels of cognitive engagement ... to focus their thinking and activity" (Oliver 2013, 85). In many institutions and disciplines, educators and learning designers may have a largely solo experience, with relatively few opportunities for engaged thoughtful discussion about practice through holistic peer review, scholarly considerations of the evidence base, communities of practice and/or individual 
ASCILITE 2021

Back to the Future

mentoring. Learning to write, reflect, think and rewrite within the genre of a reflective narrative for professional recognition is thus very much a development part of the process of developing a conscious reflective practice. How wonderful then to see CMALT and other professional recognition mentoring enacted through group interactions, communities of practice and professional learning communities alongside the traditional one-to-one relationships (Pellegrino et al., 2014; Lunsford et al, 2017). Sharing one's educational practice orally within a small group has long been known to be of great value for educators (e.g., McCormack and Kennelly, 2009; Farrell, 2015). Groups successfully supporting peer cohorts towards CMALT recognition include the multiinstitution Bloomsbury Learning Exchange (2019) in London, the UCL contingents, and the online cohorts supported by the CMALT cMOOCs (Cochrane and Naryan, 2017).

For the purposes of this paper we have reserved the concept of reflective coaching for the specific process of a much deeper engagement between a single pair - the mentor-mentee or coach-coachee dyad — as the former supports the other to reflect on personal narrative writing about practice. What we have come to understand is the empowerment and depth of reflection that comes - and stays - when it feels safe to really 'let someone in' to one's practice as an educator or educational designer, allowing them to question, probe, suggest and encourage a deeper form of reflection on practice over a significant period of time and always in the context of writing the personal narrative. That this then cannot be prevented from becoming a two-way process is necessarily human. At this point, it is time for this paper to allow the personal narrative genre to take over, as its authors explore their two experiences of preparing CMALT portfolios ten years apart, and coming together for the more recent one in a reflective coaching dyad.

\section{Case Study: A Tale of Two CMALTS}

After the original portfolio is accepted, CMALT holders are required to complete three-yearly reporting of professional development activities to provide 'a continuous cycle of developing our understanding of what it means to be a Learning Technologist and what we understand to be good or best practice' (Deepwell, 2018). In 2018, after mapping of CMALT criteria against other professional competency frameworks (e.g., UK Professional Standards Framework for Teaching and Supporting Learners in Higher Education 2011), Deepwell (2021) reports that the CMALT Accreditation Framework was expanded to encompass three experientiallydetermined categories-Associate CMALT, CMALT and Senior CMALT (12, 232 and 15 awardees respectively - as reported by ALT on its website October 2021; Association for Learning Technology, 2021). To clarify the context of the following case study then, both applicants (2011 and 2021) were applying for CMALT.

\section{Reflections on CMALT: The perspective of the 2011 applicant}

In 2011, I was an academic developer in an Australian research-intensive university. I saw many wonderful educators but very few ways for them to gain external esteem for their teaching practice beyond the few highly competitive teaching awards. Present at the Higher Education Academy (HEA) launch that year of the revised UKPSF and the associated HE fellowships, I started what later became a highly driven journey towards the 'what if?' of broad-based PR for Australian university educators. Paradoxically, considering later outcomes (Beckmann, 2016), my own scope for HEA fellowship at that time was limited by the constraints of the application criteria. However, as a learning technology specialist, I was already a member of the UK-based Association for Learning Teaching (ALT) and Ascilite. With the idea of PR ringing in my brain, the potential of CMALT attracted me. Despite what turned out to be a significant struggle with the portfolio structure and the reflective approach, in late 2011 I successfully submitted my CMALT portfolio as (I think) the first Australian to do so. Ascilite was already deliberating a more formal relationship with ALT in relation to CMALT, and my first-hand experience contributed positively. The rest, as they say, is history: CMALT Australasia was launched by ALT's John Slater at the 2012 Ascilite Conference.

My immediate response to my own CMALT success was to share information and guidance to other potential applicants in my institution. However, the scope of the portfolio felt too onerous for many unsure of what PR could offer. While my desire for a CMALT cohort did not eventuate, I did mentor one person to CMALT success (2014). By this time, I had caught the PR bug, having recognised the great opportunities for professional development that lay in reflective coaching, especially through reflective questioning (Sofo, Yeo and Villafañe, 
ASCILITE 2021

Back to the Future

2010). By continually asking key, nested questions (How? What? Why? So what?) and the 'five whys' (Ohno, 1988), I have since helped many hundreds of individuals - not only academics but also professional staff who support learners (Beckmann, 2017) — to think deeply about their practices as they write first-person personal narratives to achieve PR.

Then, in the midst of the global upheaval caused by COVID-19-which blasted the final bastions of resistance to online learning by making it the only teaching pathway - it was time to update my own CMALT portfolio, to review my own professional development and professional learning in the context of the CMALT core principles and values, and to engage in my own reflections on my own practice. I introduced my reflections on my recent professional learning like this:

CPD events do add immeasurably to my understanding, but at this stage of my career ... it is often my reflective and collaborative learning with peers that provides my most powerful professional learning 'aha' moments. As I mentor university staff clients towards professional recognition ... our in-depth discussions means I also learn about, and appreciate, their expert teaching practice. For example, this year through two wonderful mentees in Business and Engineering I have learned much about STACK design allowing for complex, scaffolded and randomly-generated multiple-choice questions in Moodle. I found myself reminiscing on how I had tried (but failed) to do the same thing by writing a program in Apple Pilot in the early 1980s. ... Constantly seeing the higher education context through the eyes and reflections of others-from diverse disciplines, cultures, backgrounds, universities_-remains a deep privilege as I discover so many new motivations, experiences, challenges, modes of collaborating, and especially ways of leading.

Updating my CMALT thus led me to think more directly and more deeply about my reflective coaching as a primary form of professional learning. I recognised it as very much a two-way process. As a mentor, I am also constantly a peer learner. As a reflective coach in the context of professional recognition, I become highly sensitised to the nuances of practice of the person I am supporting. This thinking inspired me to suggest CMALT to my (co-author) colleague as a 2021 venture in which I would be her guide. She immediately grasped the opportunity, and we continued our already-established reflective coaching discussions about her technologycentred innovations in university teaching, but now in the structured context of CMALT.

\section{Reflections on CMALT: The perspective of the 2021 applicant}

After my first online teaching experience many years ago, I realised that simply adopting my peers' practice of 'putting the textbook online' was not the way to reach my students, nor the way I wanted to teach. Thus, for well over a decade I have actively sought to improve online learning experiences. I am an evidence-based practitioner and educator, teaching very large fully online specialist classes. Digitally curious and competent, with extensive experience of technologies in communication industries long before my career in higher education, I have always put the 'technological cart after the pedagogical horse' (Sankey 2019). I first identify problems in the teaching process or students' needs, then review how readily available technologies could help me address this problem effectively. My innovation in this space has become a notable and acknowledged point of differentiation in my teaching, while sharing my practice informally across my $4 \mathrm{Cs}$ - classroom, corridor, campus and community — has seen me become a transformational influence on others.

While personal narratives of my strategies and impacts have already led to recognition of my teaching practice at institutional, national and international levels, I was particularly interested in CMALT as an unparalleled opportunity to be reviewed and benchmarked specifically for my practice in relation to learning technologies. I find it relatively easy to write about what I do, but more difficult to link and contextualise my practice and evidence to specific criteria. I knew reflective coaching for my CMALT application - unpacking each criterion and exploring my work reflectively in the context of my practice-would provide rich professional development.

Unlike my other PR ventures, CMALT required me to put my work with technologies at the heart of my personal narrative, instead of on the periphery, allowing me to engage in much deeper reflection as an educator, especially in thinking about my impact. It was the Wider Context ("understanding and engaging with legislation, 
ASCILITE 2021

Back to the Future

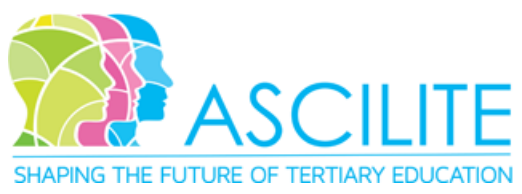

policy or standards") criterion that made me really question and unpack more thoroughly the various legislative structures that, knowingly and unknowingly, impact my life as a teacher. I realised that I actually engage much more deeply than I perhaps realised with new policies and standards, not because I am interested in the legislation as such but because I am interested in the teaching. For example, my use of technology related to academic integrity over many years has seen me learn to drill down into the utilitarian features of each technology but then also into the actual underlying standards themselves, so that I could see how to use the technology to meet the standards most effectively. I actively choose to comment on draft standards, or sit on review panels of standards, policies or procedures, because I want them to make sense in my practice as an educator. I found I could write about my expertise in this context, whereas I had not recognised that expertise previously, as the following short extract shows.

As a member of the Turnitin global community, I am able to read and comment on relevant blogs and forums on integrity issues such as contract cheating and word spinning, activities that can be both born of technology and also discoverable by using technology to unpack practices. This gives me a strong and up to date background in relevant issues. At institutional level, in 2019 I sat on the University's Advisory Committee to update the policy (an ongoing necessity with the speed of adaptation of technology and contract cheating services).

The reflective coaching I have experienced for CMALT and other PR has really helped me understand what differentiates me as an educator using technology, and required me to examine critically the goals, values and strategies I have internalised in my daily practice. For example, I can now articulate some of my key approaches -I focus on voice as feedback; I look for innovations through technologies 'hidden in plain sight'; I use learning analytics as tools to enhance student engagement and wellbeing; I have developed key strategies to minimise the potential cognitive overload on students of adding new technologies to their learning lives (Kalyuga and Liu, 2015); I see dialogic feedback as a key feature of future online learning (Gribble and Wardrop, 2021); and I am dedicated to more effective student-centred approaches to academic integrity (Turnitin 2020). For me PR provides external confirmation of my approaches, strategies and outcomes; validates my leadership so I feel confident to advise others; contributes to my sense of career coherence; and gives me a holistic, strategic vision for my impact beyond individual students and courses.

After I had completed the final draft of my 2021 portfolio and discussed it with my coach, we reviewed the themes in my coach's 2011 submission, expecting to see significant differences given the huge advances in the technologies themselves and the new dominance of devices, social media and the internet. Instead, we were surprised by the significant similarities in our portfolios (Table 1): we were seeing evolution not revolution.

\section{Conclusion}

Professional recognition can be 'the difference that makes the difference'. Though it undoubtedly takes time and real effort to reflect on one's practice in writing or through other media, the outcomes are very rewarding. The esteem of peer-reviewed standards-based recognition such as CMALT can be a real point of differentiation in applying for a new job, a promotion, or simply wanting to be 'seen'. However, in the preparation of a personal narrative as the central pillar of a portfolio, it is the inner journey of reflection rather than the outer path of career that has the potential to make the greatest difference. Reflective coaching asks the crucial question 'Why do you do what you do in the way that you do it?'. This question from those who share our scope of activitywhether mediated through a group of peers or more individualised, as the authors of this paper experiencedprovides many opportunities for personal insight into ourselves as professionals and our specific practice as learning technologists and educators. Reflective coaching during the 2021 CMALT journey provided a powerful two-way magnifying mirror, helping both coach and coachee on their reflective journeys and unexpectedly providing a time capsule back to 2011 showing that while everything had changed, nothing had changed. For this paper's authors, writing for PR has opened new reflective doors, and suggested many perspectives and views not previously considered or explored. By sharing the load, reflective coaching has made the process of creating personal narratives richer, more energised and more enjoyable, generating professional learning that we clearly see as self-directed, evaluative and future looking. 
Table 1: Topics addressed in two CMALT applications 10 years apart

\begin{tabular}{|c|c|c|c|}
\hline $\begin{array}{l}\text { CMALT } \\
\text { Criterion } \\
\end{array}$ & Topic areas in 2011 & Topic area in 2021 & Comments \\
\hline $\begin{array}{l}\text { Operational Issues } \\
\text { a. Understanding } \\
\text { constraints/ } \\
\text { benefits of } \\
\text { different } \\
\text { technologies } \\
\text { b. Technical } \\
\text { knowledge/ability } \\
\text { in use of learning } \\
\text { technology } \\
\text { c. Supporting } \\
\text { deployment of } \\
\text { learning } \\
\text { technologies }\end{array}$ & $\begin{array}{l}\text { a. Comparing/contrasting } \\
\text { learning management systems } \\
\text { (LMS: Sakai, WebCT, Moodle). } \\
\text { Teaching academics about } \\
\text { lecture-capture software } \\
\text { (Camtasia, Captivate). } \\
\text { Evaluation of Language Lab. } \\
\text { b. LMS (Moodle) site design; } \\
\text { innovations using first } \\
\text { generation iPads, interactive } \\
\text { whiteboards. Attending } \\
\text { conferences/workshops. } \\
\text { c. Providing academics with } \\
\text { support on using technology } \\
\text { through professional } \\
\text { development, individual } \\
\text { guidance and small grants for } \\
\text { innovations. }\end{array}$ & $\begin{array}{l}\text { a. Understanding key } \\
\text { strengths and limitations of } \\
\text { using all features of already } \\
\text { deployed university-wide } \\
\text { technologies and enterprise } \\
\text { systems - maximizing } \\
\text { opportunities 'hidden in plain } \\
\text { sight'. } \\
\text { b. Ability to source, compare } \\
\text { and appraise easy to access } \\
\text { and affordable technology to } \\
\text { support learning outcomes. } \\
\text { c. Sharing practice and } \\
\text { mentoring others to take up } \\
\text { opportunities systems and } \\
\text { technologies. }\end{array}$ & $\begin{array}{l}\text { Whereas } 2011 \text { was more } \\
\text { about choosing an LMS, } \\
\text { accepting multiple platforms } \\
\text { operating simultaneously, } \\
2021 \text { is about using what is } \\
\text { available: institutions are now } \\
\text { locked into enterprise } \\
\text { systems. Technical skills are } \\
\text { always helpful, but more } \\
\text { important in } 2021 \text { is excellent } \\
\text { digital literacy. Building } \\
\text { confidence in technology } \\
\text { users-both educators and } \\
\text { students- remains central to } \\
\text { influence and impact. }\end{array}$ \\
\hline $\begin{array}{l}2 \text { Learning, } \\
\text { teaching and } \\
\text { assessment } \\
\text { a. Understanding } \\
\text { of teaching, } \\
\text { learning, } \\
\text { assessment } \\
\text { processes } \\
\text { b. Understanding } \\
\text { of target learners }\end{array}$ & $\begin{array}{l}\text { a. Professional development } \\
\text { through qualifications in higher } \\
\text { education: PR only through } \\
\text { teaching awards. } \\
\text { b. Diverse learner groups } \\
\text { (teaching academics, and their } \\
\text { students; research students as } \\
\text { tutors; academics as students) }\end{array}$ & $\begin{array}{l}\text { a. Professional development } \\
\text { through qualifications in } \\
\text { higher education, virtual } \\
\text { international conferences: PR } \\
\text { through teaching awards and } \\
\text { multiple global schemes. } \\
\text { b. Diverse learner groups } \\
\text { (undergraduate/postgraduate } \\
\text { students; research students as } \\
\text { tutors; academic colleagues } \\
\text { across disciplines). Much } \\
\text { greater student diversity } \\
\text { (globalisation), so more need } \\
\text { for extensive emphasis on } \\
\text { inclusive practices. }\end{array}$ & $\begin{array}{l}\text { More similarities than } \\
\text { differences. Despite so much } \\
\text { research on learning with } \\
\text { technology between } 2011 \text { and } \\
2021 \text {, the fundamentals of } \\
\text { student-centred learning } \\
\text { remain key to good practice. } \\
2021 \text { shows greatly increased } \\
\text { richness of global peer } \\
\text { connections and diverse } \\
\text { thinking through pandemic- } \\
\text { boosted availability of virtual } \\
\text { conferences, and unparalleled } \\
\text { global emphasis on online } \\
\text { learning. }\end{array}$ \\
\hline $\begin{array}{l}3 \text { The Wider } \\
\text { Context } \\
\text { a. Understanding } \\
\text { and engaging with } \\
\text { legislation } \\
\text { b. Second } \\
\text { legislative area or } \\
\text { policy or standard }\end{array}$ & $\begin{array}{l}\text { a. Student privacy issues versus } \\
\text { pedagogical/evaluation issues. } \\
\text { University Legal Office } \\
\text { determining whether Privacy Act } \\
1988 \text { required activity report } \\
\text { data to be removed from LMS. } \\
\text { Terms of services: potential } \\
\text { impacts of staff or students } \\
\text { signing up to external providers } \\
\text { b. Commenting on institutional } \\
\text { Draft Inclusive Learning policy } \\
\text { from TEL perspective. }\end{array}$ & $\begin{array}{l}\text { a. Student integrity issues, } \\
\text { use of aligned software, } \\
\text { contract cheating. Interacting } \\
\text { university-wide with Central } \\
\text { Integrity Office. Ability to } \\
\text { interpret diversity of } \\
\text { plagiarism issues and align } \\
\text { with legislation. } \\
\text { b. Student privacy issues } \\
\text { versus pedagogical/ } \\
\text { evaluation issues. }\end{array}$ & $\begin{array}{l}\text { Emergence of information } \\
\text { literacy and social media has } \\
\text { reduced users' concerns } \\
\text { about privacy, but these still } \\
\text { underpin actions taken with } \\
\text { or through data. In } 2021 \\
\text { inclusive practice/accessibility } \\
\text { now mediated through } \\
\text { technology. Also in } 2021 \\
\text { student integrity and contract } \\
\text { cheating legislation impacts } \\
\text { teaching with technology. }\end{array}$ \\
\hline $\begin{array}{l}4 \text { Communication } \\
\text { and working with } \\
\text { others }\end{array}$ & $\begin{array}{l}\text { Leading cross-institutional TEL } \\
\text { workshop for practice sharing. } \\
\text { Communities of practice. } \\
\text { Providing guidance to individual } \\
\text { educators. Leading professional } \\
\text { development. }\end{array}$ & $\begin{array}{l}\text { Many avenues for sharing } \\
\text { practice: leading campus- } \\
\text { wide community of practice, } \\
\text { highly diverse forums; global } \\
\text { platforms for sharing with } \\
\text { peers via conferences. }\end{array}$ & $\begin{array}{l}\text { Peer learning always strong. } \\
\text { Different policies, platforms, } \\
\text { tools created limits in } 2011 . \\
\text { By } 2021 \text {, convergent evolution } \\
\text { of technologies, global } \\
\text { systems/platforms, and } \\
\text { pandemic drivers supported } \\
\text { much more peer-sharing. }\end{array}$ \\
\hline
\end{tabular}




\begin{tabular}{llll}
\hline $\begin{array}{l}\text { Specialist Area of } \\
\text { independent }\end{array}$ & $\begin{array}{l}\text { Evaluating the impact of } \\
\text { technology on students: design- }\end{array}$ & $\begin{array}{l}\text { Technology for feedback and } \\
\text { assessment: embedding }\end{array}$ & $\begin{array}{l}\text { Specialist areas of practice } \\
\text { develop organically, but }\end{array}$ \\
practice & $\begin{array}{l}\text { based research and action } \\
\text { research. }\end{array}$ & $\begin{array}{l}\text { voice, identifying integrity, } \\
\text { online rubrics/marking. }\end{array}$ & holistic strategies still \\
& & & underpin online learning.
\end{tabular}

\section{References}

Anderson, T., Moir, T., Nates, R., Hooper, P., Whittington, C., Protheroe, M., Hadrup, M. \& Beckerleg, M. (2020). Trying-out digital technologies in trying times: A collection of observations from a collegial adventure during Covid-19. https://www.aaee2020.com.au/wpcontent/uploads/2020/11/AAEE2020_paper_102.pdf

Association for Learning Technology. (2016). CMALT Guidelines. https://www.alt.ac.uk/sites/default/files/assets_editor_uploads/documents/CMALT_guidelines.pdf

Association for Learning Technology. (2019). CMALT Assessment Guidelines. https://www.alt.ac.uk/sites/alt.ac.uk/files/public/CMALT\%20Assessment\%20Guidelines\%202019.pdf

Association for Learning Technology. (2021). CMALT Holders' List. https://www.alt.ac.uk/certifiedmembership/cmalt-holders

Beckmann, E.A. (2016). Teaching excellence: Recognising the many as well as the few. In M. Davis \& A. Goody (Eds.), Research and Development in Higher Education: The Shape of Higher Education, 39, 13-22. http://www.herdsa.org.au/publications/conference-proceedings/research-and-development-higher-educationshape-higher-1

Beckmann, E.A. (2017). Professional staff, professional recognition: Bringing learner support staff into the fellowship of university educators. In: Bossu, C. \& Brown, N. (Eds.) Professional and Support Staff in Higher Education. Springer Science.

Benson, S.A., Smith, A.C., \& Eubanks, D.B. (2013). Developing scholarly teaching at a research university: Using learning communities to build capacity for change. In Salter, D. (Ed.) Cases on Quality Teaching Practices in Higher Education. IGI Global. (pp. 212-227)

Bloomsbury Learning Exchange. [2019]. Certified Membership of the Association of Learning Technology. https://www.ble.ac.uk/cmalt.html

Bornais, J., \& Buchholz, A. C. (2018). Becoming a more reflective teacher by serving on a university teaching awards committee. Transformative Dialogues: Teaching and Learning Journal, 11(1). https://journals.kpu.ca/index.php/td/article/download/783/267

Cochrane, T., \& Narayan, V. (2017). CMALT cMOOC: Developing a scalable lecturer professional development framework. https://2017conference.ascilite.org/wp-content/uploads/2017/11/FullCOCHRANE.pdf

Deepwell, M. (2018). Senior CMALT: Open access research and promoting equality in learning technology. October 28, 2018. https://marendeepwell.com/?p=1805

Deepwell, M. (2021). Association for Learning Technology: CMALT and other frameworks. https://www.alt.ac.uk/certified-membership/cmalt-and-other-frameworks

Farrell, T.S. (2015). Teachers talking about teaching: Creating conditions for reflection. Tesl-Ej, 19(3).

Gallardo M. (2019) Transcultural voices: Exploring notions of identity in transnational language teachers' personal narratives. In: Gallardo M. (Ed.) Negotiating Identity in Modern Foreign Language Teaching. Palgrave Macmillan.

Gribble, L. \& Wardrop, J. (2021). Maintaining 'incidental' feedback in synchronous online learning environments. In Baughan, P. (Ed.) Assessment and Feedback in a Post-Pandemic Era: A Time for Learning and Inclusion. 68-76. Advance HE. https://kar.kent.ac.uk/90382/1/AdvHE_Assessment_Feedback_postpandemic_1625736998.pdf\#page=71

Kalyuga, S. \& Liu, T.C. (2015). Managing cognitive load in technology-based learning environments. Educational Technology \& Society, 18(4), 1-8.

Kara, N., Çubukçuoğlu, B., \& Elçi, A. (2020). Using social media to support teaching and learning in higher education: An analysis of personal narratives. Research in Learning Technology, 28. https://doi.org/10.25304/rlt.v28.2410

Kuiper, A.C. \& Stein, S.J (2019) Engaging, innovating and inspiring: The paradox of the mediated voice of award-winning teachers, Higher Education Research \& Development, 38(6), 1197-1212.

Langellier, K. M. (1989) Personal narratives: Perspectives on theory and research. Text and Performance Quarterly, 9:4, 243-276. https://doi.org/10.1080/10462938909365938 


\section{ASCILITE 2021}

Back to the Future

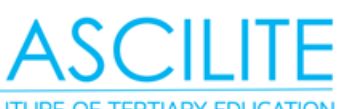

SHAPING THE FUTURE OF TERTIARY EDUCATION

Lunsford, L. G., Crisp, G., Dolan, E. L., \& Wuetherick, B. (2017) Mentoring in higher education. (pp.316-334) In: D. A. Clutterbuck, F. K. Kochan, Laura Lunsford, N. Dominguez, \& J. Haddock-Millar (Eds.). The SAGE Handbook of Mentoring. Sage.

McCormack, C., \& Kennelly, R. (2009). Talking about Teaching and Learning (TATAL). HERDSA News, $31(1), 8-10$.

Moen, T. (2006). Reflections on the narrative research approach. International Journal of Qualitative Methods, 5(4), 56-69.

Ohno, T. (1988). Toyota Production System: Beyond Large-Scale Production. CRC Press.

Oliver, R. (2013). Using technology in learning and teaching: Making the right choices involves understanding the problems to be solved. (pp. 76-95) In Salter, D. (Ed.) Cases on Quality Teaching Practices in Higher Education. IGI Global.

Pellegrino, K., Sweet, B., Kasner, J., Russell, H., Reese, J. (2014). Becoming music teacher educators: Learning from and with each other in a professional development community. International Journal of Music Education, 32, 462-477. https://doi.org/10.1177/0255761413515819

Sankey, M. (2019). Putting the pedagogic horse in front of the technology cart. https://blog.ascilite.org/puttingthe-pedagogic-horse-in-front-of-the-technology-cart/

Sellers, K., Amatullah, T. and Malin, J. R. (2021). Learning to level up: personal narratives about mentoring for the professoriate during a crisis", International Journal of Mentoring and Coaching in Education, Vol. 10 No. 2, pp. 173-187. https://doi.org/10.1108/IJMCE-01-2021-0006

Sofo, F., Yeo, R. K., \& Villafañe, J. (2010). Optimizing the learning in action learning: Reflective questions, levels of learning, and coaching. Advances in Developing Human Resources, 12(2), 205-224.

Turnitin (2020). Turnitin 2019 Global Innovation Award Winners. https://www.turnitin.com/stories/lynn-gribble

Beckmann, E.A., \& Gribble, L.C. (2021). CMALT 2011 and 2021: Personal narratives for professional recognition. In Gregory, S., Warburton, S., \& Schier, M. (Eds.), Back to the Future - ASCILITE '21. Proceedings ASCILITE 2021 in Armidale (pp. 345-351). https://doi.org/10.14742/ascilite2021.0150

Note: All published papers are refereed, having undergone a double-blind peer-review process.

The author(s) assign a Creative Commons by attribution licence enabling others to distribute, remix, tweak, and build upon their work, even commercially, as long as credit is given to the author(s) for the original creation.

(C) Beckmann, E.A. \& Gribble, L.C. 2021 
